\title{
Redefining Sovereignty, Consolidating a Network: Monitoring the 1990 Nicaraguan Elections*
}

\author{
Arturo Santa-Cruz \\ Department of Pacific Studies, Social Sciences and Humanties Center, \\ UNIVRSITY OF GUADALAJARA
}

\begin{abstract}
Resumen
Los procesos electorales son hoy en día eventos internacionales y la observación internacional de elecciones (OIE) una práctica institucionalizada en la política mundial que ha redefinido parcialmente el concepto de soberanía estatal. Este trabajo trata de un caso fundacional en el proceso de normalización de la OIE: las elecciones nicaragüenses de 1990. Por primera vez en la historia, la Organización de las Naciones Unidas, la Organización de Estados Americanos, y una miríada de organizaciones no gubernamentales monitorearon un proceso electoral conjuntamente en un Estado soberano. Este trabajo analiza el caso nicaragüense a la luz de la estructura normativa del hemisferio occidental, la cual, como se argumenta, jugó un papel importante tanto en él como en la eventual normalización de la OIE.
\end{abstract}

\begin{abstract}
National elections are now international events-and international election monitoring (IEM) an institutionalized practice in world politics that has partially redefined state sovereignty. This work is about a foundational case in the process of IEM's normalization: the 1990 Nicaraguan elections. For the first time ever, the United Nations, the Organization of American States, and a myriad of non-governmental organizations monitored an electoral process in a sovereign country. I consider the Nicaraguan experience in light of the wider normative structure of the Western Hemisphere, which I argue, played an important role both in it and in IEM's eventual normalization.
\end{abstract}

PALABRAS CLAVE • International Election Monitoring • Sovereignty • Norms • Western Hemisphere - Idea • Latin America • Nicaragua

National elections are now international events-and International election monitoring (IEM) an institutionalized practice in world politics. Thus, for instance, the United Nations, the Organization of American States, the Commonwealth, and the Organization on Security and Cooperation of Europe all engage on it. But election monitoring is not the monopoly of intergovernmental organizations (IGOs). There are many nongovernmental organizations (NGOs), domestic and international, that are actively involved in this practice as well; the Carter Center, the International Human Rights Law Group, and the Washington Office on Latin America, are three well known examples.

* I I would like to thank Peter Katzenstein, Valerie Bunce, Matthew Evangelista, Kathleen O'Neill and an anonymous reviewer for their comments on previous versions of this article. 
But the institutionalization of IEM is recent. Twelve years ago, none of the IGOs mentioned above systematically observed electoral processes in sovereign states. Interestingly, though, NGOs have been regularly monitoring elections since the early 1980s. The question thus arises as to why has international election watching come to figure so prominently in the international agenda in a little over a decade. Furthermore, is it the case that IGOs followed NGOs in embarking in this practice?

These questions are relevant because they address the issue of the changing notion of state sovereignty. In the modern state system issues of domestic governance in sovereign states have traditionally been placed out of the realm of international action. Thus, in the post-war period national elections have been considered to fall within Article 2 (7) of the United Nations (UN) Charter, which establishes that the organization and its member states cannot intervene "in matters which are essentially within the domestic jurisdiction of any state." Hence, in 1988 UN SecretaryGeneral Javier Pérez de Cuellar noted that the United Nations "does not send observers to elections" in sovereign states (in Stoelting, 1992: 372).

This article is about a foundational case in the process of IEM's normalization: the 1990 Nicaraguan elections. The Nicaraguan experience was a watershed in the history of IEM-and in the partial redefinition of sovereignty this practice has implied. For the first time ever, the UN, the Organization of American States (OAS), and a myriad of NGOs monitored an electoral process in a sovereign country. As Robert Pastor has put it, by inviting international monitoring missions the Nicaraguan government was "crossing [the] Rubicon of sovereignty... Up until that moment, most governments... viewed elections as internal matters... With the official invitations [to the OAS, the UN, and the Carter Center], the Nicaraguans transcended conventional definitions of sovereignty (Pastor, 2002: 231)."

I consider the Nicaraguan case in light of the wider normative structure of the western hemisphere, which I argue played an important role both in it and in the eventual normalization of IEM. In my argument, both normative and strategic considerations are significant for explaining the Sandinistas decision to allow foreign observers. This piece is organized as follows. In the first section I introduce my general argument on the normative structure of the Americas, state sovereignty, and IEM. In the second I consider the 1990 elections, focusing on the work of three international actors: the Carter Center (henceforth CC), the OAS, and the UN.

\section{THE WESTERN HEMISPHERE'S NORMATIVE STRUCTURE, IEM, AND STATE SOVEREIGNTY}

I argue that it was the combination of a series of systemic and domestic factors in the Americas that made the environment in the hemisphere particularly conducive to the emergence of IEM. Significantly, though, it arose in a delimited part of the Americas: Latin America. This is not to suggest that the region was self-contained in this respect. North America, and specifically the United States, played a key role in the emergence of IEM in Latin America. Hence, my inquiry considers the interaction between these two main regions of the hemisphere. I am not saying that the these subcontinents are two naturally independent regions. In fact, during the nineteenth century the United States often served as a "role model" for the nascent Latin American states, which were frequently ready to follow the republican institutions of their northern neighbor. The point is to look into the factors that might have made of the Americas a unique international (sub)system, and into the interaction that created two distinguishable regions within the hemisphere. These two issues, 
the Americas as a region, and Latin America within the Americas, constitute the historical structure that made the emergence of IEM possible.

The first of the two issues, the Americas as a region, is closely related to what has come to be known as the "Western Hemisphere Idea" (WHI). As early as 1813, Thomas Jefferson wrote that the governments to be formed in the nascent states,

will be American governments, no longer to be involved in the never-ceasing broils of Europe. The European nations constitute a separate division of the globe; their localities make them a part of a distinct system... America has a hemisphere to itself. It must have a separate system of interest which must not be subordinated to those of Europe (in Callcott, 1968: 14; my italics). According to Arthur P. Whitaker, Jefferson's statement was "the first flowering" of the WHI (Whitaker, 1954: 29).

By WHI Whitaker refers to "the proposition that the peoples of this Hemisphere stand in a special relationship to one another which sets them apart from the rest of the world (Ibid.: 1)." Interestingly, the perception of being "apart from the rest of the world" does not necessarily imply the existence of a community of interests among the states of the Americas. In effect, implicit in this "special relationship" is the interplay not only of the new world's states, but also of its two main sub regionsa relationship that most of the times has been a contentious one. It is important to note this because it is common to equate western hemispherism with regional co-operation. For instance, Javier Corrales and Richard Feinberg define "Hemispherism" as "the active attempt by nations in the hemisphere to redirect their foreign policies in favor of a closer and coordinated cooperation with one another (in Corrales and Feinberg, 1999: 2)." The focus is then often shifted to what are defined as formal institutions of co-operation, such as the OAS or the Inter-American Development Bank. But as Whitaker himself made clear in his seminal text, "the distinction between the idea and its various political expressions... should be constantly kept in mind (Whitaker, 1954: 5)." The precision is significant because it makes clear that the "idea" refers to patterned interaction per se, not to cooperation. It is the "Idea" as a normative structure producing order in the sociological sense, more than as its institutional manifestations producing co-operation, that interests me (Wendt, 1999: 251.).

I thus take the WHI as normative structure to be the dialectical interplay of the Americas as a region, and of the two sharply contrasting regions within it. By producing and reproducing both the fundamental-and often contradictory-values holding the region together, and a social order among the members of the hemisphere, the interplay gave rise to a distinctive idea of state sovereignty. And it was this idea of sovereignty, I maintain, that allowed IEM to emerge in the Americas before anywhere else. This is so because the composite understanding of sovereignty in the Americas had two constitutive elements: representative government (and later human rights broadly speaking) and non-intervention. Thus, for instance, Article 5 of the OAS charter notes, "The solidarity of the American States and the high aims which are sought through it require the political organization of those States on the basis of the effective exercise of representative democracy," while also stating that "International order consists essentially of respect for the personality, sovereignty and independence of States." It was the ever-present tension between these two components of the regional understanding of sovereignty, an understanding that evolved for over a century, that allowed the states in the hemisphere to embark in IEM as early as 1962 with ground-breaking OAS missions to Costa Rica and the Dominican Republic (even if the monitoring carried out back then was more symbolic than real). At bottom, then, IEM is about state sovereignty. 
Taking a constructivist stance, I conceive of sovereignty as a structural component of the international system, one that has been produced and reproduced in tandem by the practice of state and nonstate actors (Santa Cruz, 2000: 132-3). As a structural element, sovereignty does not dictate behavior, but rather shapes the identity and interests of the actors. Furthermore, sovereignty has no grounding in itself. It is what the constitutional structure underpinning the existence of the states makes of it; without this grounding, sovereignty is an empty vessel, incapable of providing a basis for state interaction. At bottom, sovereignty is about legitimacy-legitimacy understood as "the normative belief by an actor that a rule or institution ought to be obeyed (Hurd, 1999: 381)." But sovereignty is also partially malleable. I say partially because, being a structural element, it is by definition not completely malleable-at least within certain periods. Being a social construct, though, it remains plastic by definition. Thus, as Cynthia Weber has put it, "The legitimate privileges and competencies of states are markedly different in the eighteenth, nineteenth, and twentieth centuries (Weber, 1995: 2)."

IEM is one way through which the meaning of sovereignty has gradually changed. Its effect in the construction of sovereignty is indeed straightforward: the recognized rights of states are now explicitly delimited by an international element. As UN Secretary-General Boutros Boutros-Ghali put it in 1992: "The sovereignty of states must be considered under the sovereignty of human rights (in Inter-American Dialogue, 1992: 31)." And thanks to the work of several monitoring organizations, the right to free and fair elections was widely recognized by the early 1990s as a human right. Interestingly, though, this change in the system-wide understanding of human rights and sovereignty had it origins in the Americas, where IEM resonated with the normative structure of the continent, the WHI.

It was in the Americas, after all, where NGOs started to systematically monitor elections. Their pioneering work was partly made possible by the continental discourse on human rights and democracy. And it was only after the entrance of NGOs into IEM, often interacting with IGOs, that this practice became "real" (in the sense of being performed thoroughly). That is why by the late 1980 s and early 1990s, when a state accepted monitors, it was engaging in a partial redefinition of its sovereignty. The composite, implicit understanding of state sovereignty enshrined in the WHI had thus become explicit. I now consider in more detail a cornerstone in IEM's history: the 1990 Nicaraguan elections.

\section{THE ROAD TO THE 1990 ELECTIONS}

2578 international observers were present on election day in the 1990 Nicaraguan electoral process. The largest contingents came from the OAS and the UN, but the NGOs' combined contingent was also strong, with almost 2000 observers. ${ }^{1}$ The Nicaraguan elections were framed in terms of a regional peace process. That is, the timing and nature of elections was informed by the Contadora Initiative, and the Esquipulas Agreements (Esquipulas I and II, the latter also known as Arias Plan), all of which aimed at bringing peace to Central America (see Rico, 1990). As Jennifer McCoy has noted, both IGOs framed their acceptance of the Nicaraguan invitation within the Central American Peace Plan (McCoy, 1998: 59). Thus, for instance, the UN Secretary-General, when justifying his organization's presence in Nicaragua, noted that the elections had an indisputable international dimension: the regional peace process.

The figure was provided by Rosa Marina Zelaya, member of Nicaragua's Supreme Electoral Council at the time of the elections. Interview, Managua, 3 October 2001. 
The peace process permeated the domestic electoral environment as well. As Marian Fiallos, President of Nicaragua's Supreme Electoral Council (CSE) at the time of the 1990 elections has noted, the presence of international observers was framed in terms "of contention of a regional war (Interview with Fiallos, León, 5 October 2001)." Similarly, for Antonio Lacayo, then at the National Opposition Union (UNO), "the 1990 elections in Nicaragua need to be seen within the context of a war, in which this country was immersed since the 1980 (Interview with Lacayo, Managua, 6 October 2001)." This framing is important because it led the Sandinista government to actively seek international observation of the electoral process. As CSE-member Rosa Marina Zelaya has noted, the international monitoring of the 1990 elections was important because "we were in war at that moment, and Nicaragua needed that those elections be credible (Interview with Zelaya)."

But unlike the previous, 1984 electoral process, which had not achieved full credibility either at home or abroad in spite of it having been monitored by (mostly sympathetic) NGOs, this time the elections needed to be credible on both fronts. The Achilles' tendon of the 1984 electoral process had been the domestic dimension, with the main opposition forces boycotting the elections. This time, the presence of the full political spectrum had been guaranteed in August 1989, and the next month the political parties that formed UNO announced the nomination of Violeta Chamorro as their presidential candidate, and Virgilio Godoy, a former cabinet member in the Sandinista government, as their vice-presidential candidate. On the international dimension, the participation of international observers, particularly of the OAS and the UN, agreed on in the context of the Arias Plan, gave surety to third parties that the next Nicaraguan government would be a legitimate one.

The domestic and external dimensions of the electoral process, however, were mixed to an extent that made their consideration as two discrete realms illusory. The Nicaraguan 1990 elections were certainly an international event. For UNO, the absence of international observers would have meant its non-attendance of the electoral process. As Lacayo, chief advisor to Violeta Chamorro and Minister of the Presidency in her administration put it, "For us in the opposition... the international observation [of the 1990 electoral process] was an indispensable condition... if there had not been international observation, we wouldn't have gone to the elections (Interview with Lacayo)." Similarly, the OAS partly justified its presence in Nicaragua by noting that it was welcome by all the political forces (OAS, 1990: 2). In effect, as CSE' Zelaya noted, "the perception of the citizenry, of the political parties was positive... the 21 political parties that participated [in the 1990 elections] agreed with the presence of electoral international observers... The presence of the UN and the OAS strengthened the validity of the results of the electoral body. Not because [the results] would or wouldn't have been false, but because there was a electoral-political support on the part of these missions (Interview with Zelaya)."

The consensus on the need for international observers is telling. There was of course some dissent inside the government and even within the CSE, which opposed the presence of international observers for sovereignty reasons. But as Fiallos has noted, "the situation was such that it was not possible to be toying with theories; something needed to be done to re-establish peace in Nicaragua, and [the presence of international observers in the elections] look like a good opportunity (Interview with Fiallos)." Similarly, for Lacayo the issue of foreign observers impinging upon Nicaragua's sovereignty was somewhat passé. For him, 
sovereignty had been lost long before, for us it had been lost since the moment that here many of the decisions were taken, along with government officials, by people from East Germany, Czechs, Bulgarian, Palestines, and people who were not Nicaraguan, and mainly the Soviets who came to give advise on all military aspects. That is to say that for us in the opposition sovereignty had been lost long ago, we rather had to rescue it by means of bringing democracy to Nicaragua, and by means of a government truly committed not only with rescuing our sovereignty but with an effective policy of non-alignment (Interview with Lacayo).

Nicaraguans were indeed breaking new ground with their position regarding international observers. As Zelaya remembers,

in 1990 there were governments that criticized Nicaragua for allowing electoral international observation, for being the cutting edge in this "intrusion"... that allowing the presence of international observers was damaging to Nicaragua's sovereignty, among them [the critics] some Mexican leaders, and some Cuban leaders, sectors which were somewhat wary of the possibility that sovereignty could be hurt... And they were partially right, but the fact of the matter is that the electoral international observation [of the 1990 process] was a necessary evil.

Before this time, Zelaya notes, "the issue of sovereignty, the issue of independence, all that had always been above anybody wanting to put together such an important observation" effort (Interview with Zelaya). But the Nicaraguan revolution in the context of its first decade was presented with practically no option vis-à-vis international observers: it had to accept them if it wanted to survive internationally. That is why Fiallos noted that it was no time to "be toying with theories" about national sovereignty. That is why the Nicaraguan Foreign Minister, Miguel D'Escoto did not have any qualms about the presence of international observers in the 1990 elections; for him, in any case, "the intervention was already there: it was U.S. intervention, which we never ceased having (Interview with D'Escoto, Managua, 9 October 2001)." This necessity did not prevent the Sandinistas from making of the presence of international monitors an strategic move, though. That is, they presented their decision to allow international observers as a sign of their willingness to abide by the rules of the democratic process-and made sure that the international community paid close attention to their electoral process. In the end, it was hope that the eventual approval of the three main monitoring organizations would help the revolution survive.

There were three kinds of international observers in the 1990 Nicaraguan elections, each subject to different regulations. The first and most important one was reserved for international organizations, which had special rights, immunities, and access to information. Although in theory only the OAS and the UN were in this category, in practice the CC/Council of Freely Elected Heads of Government (CFEHG) also belonged to it. The second category corresponded to "invited observers;" they were distinguished individuals or organizations such as Hemisphere Initiatives. ${ }^{2}$ A subset of this category was the diplomatic body accredited in Managua who wanted to observe the process; they received a "courtesy pass" in order to make their monitoring activities easier. Finally, uninvited observers, who could monitor the process as tourists (Interview with Zelaya. International Human Rights Law Group, 1990: 67). Thus, independent monitoring missions such as those of the Law Group or

Hemisphere Initiatives (HI) was an organization formed mainly by academic in the United States in 1989 "to observe the elections and counteract what they thought would be a repeat of the disqualifying of the 1984 elections." Interview with IH member Judy Butler, Managua, 6 October 2001. 
WOLA played an important but secondary role in the 1990 electoral process. As the Law Group put it in a pre-election report, "Three groups [of observers] in particular promise to be of key importance: the UN, the OAS, and former President Jimmy Carter's Council of Freely Elected Heads of Government (International Human Rights Law Group, 1990: 15)." There was, though, a common denominator in practically all observation efforts: US resources. As Rafael López Pintor has put it, "The importance of U.S. electoral assistance may be summarily assessed by stating that no relevant sector of Nicaraguan society was left without a share in this fund... two of the three main observer missions (OAS and Carter) and some of the minor ones (Freedom House, the Costa Rica-based Center for Electoral Assistance and Promotion) were basically financed by direct U.S. aid (López Pintor, 1998: 41-2)."

The main source of US funding was the National Endowment for Democracy (NED). In October 1989 Congress appropriated \$9 million for the "promotion of democracy" in Nicaragua. Of this appropriation eight million went to NED, which in turn granted \$4.12 million to the National Democratic Institute for International Affairs (NDI) and to the International Republican Institute (IRI), in addition to \$2.5 million for "noncampaign" activities of the opposition coalition UNO, with the rest going to a UNO-affiliated union group, and to civil education project, and to Nicaragua's CSE. Of the one million remaining from the appropriation that did not go to NED, $\$ 400,000$ went to the Carter Center, $\$ 250,000$ to the Center for Democracy, and about $\$ 400,000$ to the Inter-American Institute of Human Rights' Center for Electoral Assistance and Promotion (CAPEL) (International Human Rights Law Group, 1990: 58; Williams, 1990: 21).

In any case, the fact that an international NGO such as the CC-CFEHG was granted an status similar to that of the two participating IGOs tells something not only about the nature of the international $\mathrm{NGO}$ at issue, but also of the complexity IEM reached with the Nicaraguan elections. As Jennifer McCoy has put it, this case "illustrated active coordination between IGOs and [international] NGOs (McCoy, 1998: 59)." Nevertheless, the interaction of the three most important monitoring missions was not exempt from rivalry. It was no doubt benign rivalry, but rivalry nonetheless. As Robert Pastor, a key member of the CC team put it, "Not only were [incumbent Daniel] Ortega and Chamorro competing for power, so too were Carter, [Elliot] Richardson [the UN Secretary-General personal representative], and [OAS Secretary General João Clemente] Baena [Soares] competing, although in a more subtle and perhaps subconscious way, for attention and credit (Pastor, 2002: 251)."

In the following sections, I deal in more detail with the work of each of the three main observer missions. I start with the Carter Center because, in a way, it represents the culmination of the NGOs' effort in election monitoring in the hemisphere which, as I noted above, was instrumental in achieving IEM's normalization. I then consider the OAS mission, in order to emphasize the continuity the Nicaraguan request represented for the regional organization; finally, I review the UN involvement in the Nicaraguan electoral process, which was an unprecedented experience for the international organization.

\section{The Carter Center}

The CC was established by former president James Carter in 1982. In 1986 it hosted a conference on democracy in the Americas, which renown politicians from around the continent attended. As a result of the conference, 12 former and current heads of government from the Americas established the Council of Freely Elected Heads of Government, which was to be based at the Carter Center 
(Carter Center, 1996). The Center's staff, and president Carter in particular, became the core of the Council. Among the Council's founding goals was "to promote multilateral democratic transitions and to reinforce the consolidation of new and re-emerging democracies in the region (Ibid: 7)." Its first election monitoring mission was to Haiti in 1987, at the request of the transitional government.

The CC is a sui-generis NGO. It could be considered a semi-governmental organization. This is so for several reasons. In the first place, the influence it is able to exert is due, to a large extent, to the fact that its leader is a former U.S. president. In second place, at least occasionally, as was the case in the Nicaraguan elections, a large part of its funding comes from the U.S. government. In third place, sometimes it works at tandem with the U.S. government. During the Nicaraguan mission CC members often times informed U.S. government officials of their activities in the Central American country. Thus, for instance, Pastor mentions several occasions in which he briefed and or consulted with State Department officials (Carter Center, 1990: 32; Pastor, 2002: 238, 245, 252, 256). Furthermore, when a special commission to observe the Nicaraguan elections named by president Bush was rejected by the Nicaraguan government, the CC's mission invited some of its members to join it (New York Times, "Nicaragua Vote Monitors Confident," 23 February 1990, A3).

The CC actively sought an invitation to observe the 1990 elections. ${ }^{3}$ When president Daniel Ortega invited Carter to Nicaragua to attend the celebrations of the revolution's $10^{\text {th }}$ anniversary, he sent Pastor in his place to get an invitation (Pastor, 2002: 230). In Managua, Pastor met with Ortega and vice president Ramírez. He used the CC's recent experience in the Panamanian 1989 elections to make his case. As Pastor recalls, he told vice president Ramírez: "Here is an idea: why don't you pick the person who denounced Noriega's election as a fraud, that would certainly put you in a strong position to convince because he's established his credibility and you know he can be trusted and we would be fair (Interview with Robert Pastor, Atlanta, 5 September 2000)."

Pastor proved to be a persuasive envoy, and Carter received the government's invitation on 3 August 1989. The Sandinistas were thus acting strategically, making the most of the adverse international environment which they knew require them to invite observers. Carter officially accepted the invitation five days after receiving it (Pastor, 2002: 231). In his letter of acceptance, Carter promised Ortega that he would "work to ensure that the results of a free and fair election in Nicaragua will be respected in the United States and the rest of the world regardless of who wins or loses (New York Tiimes, "Carter to Monitor Elections Next February in Nicaragua," 9 August 1989)." Thus, Carter set out to put together a 34-member "international and bipartisan" delegation (Carter Center, 1990: 15)."

The "bipartisan" nature of the delegation clearly points to the semi-official nature of the delegation. But despite these two features, the relationship between the CC's delegation and the Bush administration was not always free of tension. As Pastor puts it:

The relationship between the Carter mission and the Bush administration was a complicated one at several levels. The fact that Carter and Bush were of different parties and had contrary views of the contras strengthened Carter's negotiating hand in Nicaragua, although it also heightened suspicion among some in the Bush administration.... At a second level was the

Strictly speaking, the mission was the CFEHG's. But for practical purposes, the Council is part of the Carter Center. Pastor (2002): 230. Thus, l'll refer to the Council's mission as the Carter's mission. 
personal relationship... there was an unhappy chemistry [between Bush and Carter]... Another important factor... was the Democratic control of Congress. Over the objections of the Bush administration, the Democrats inserted funds for the Carter Center observation into the AID budget, and when the Carter mission needed to confirm that the United States was not engaged in covert actions [for a mediation service related to the campaign], we approached the Democratic chairs of the Intelligence Committees directly (Pastor, 2002: 234).

In designing its strategy for Nicaragua, the CC relied on the work NDI had done previously, particularly in Chile. The network of observers that converged in the austral country in the context of the 1988 plebiscite became a solid foundation for the work the CC did in Nicaragua in 1989-1990. In the final report, Pastor thanks Brian Atwood, Ken Wollack, Larry Garber, and Glenn Cowan, all of whom were actively involved in NDI's monitoring of the 1988 Chilean plebiscite, "for their advice and for the model they have developed for observing elections (Carter Center, 1990: 10)." Nevertheless, the Carter Center intended from the beginning to go much further that other monitoring groups, be $\mathrm{NDI}$, the Law Group, or WOLA, had gone before. Being a high-profile organization, the CC mission was envisioned since August 1989 "not [as] an observation mission; it would be a mediation project to define the terms that would allow all sides to accept the process and respect the election results (Pastor, 2002: 237-8; italics original)." Its role was, according to the CC's Managua office director Jennifer McCoy, to "actually influence the process, trying to improve, and help level the playing field (Interview with Jennifer McCoy, Atlanta, 8 September 2000)." That is why I said before that the CC's work in Nicaragua represented, in a way, the culmination of the NGOs' effort in election monitoring in the hemisphere.

Thus, in 16-19 September co-chairs former Argentinean president Raúl Alfonsín, and Carter led the first pre-electoral visit to Nicaragua (Carter Center, 1990: 16). Delegation members met with government and electoral officials, and received assurances that its mission would have access, on par with the UN and OAS delegations, to the counting of the ballots, and would be given a copy of the vote tally sheet. The following month, from the 20 to the 23, former Venezuelan President Rafael Caldera and former Arizona Governor Bruce Babbit led a second visit (Ibid: 17). The delegation observed the last Sunday of voter registration. Although the report on the registration process was positive, the mission also noted some problems, such as the insufficient number of polling places in areas where more than 400 voters had registered, and an unbalanced access to the media that affected negatively opposition forces.

In 13-16 December, former presidents Carter and Daniel Oduber (Costa Rica), and former Washington state governor Daniel Evans led a third visit to Nicaragua in order to observe the formal start of the electoral campaign. During that visit, president Carter played an active role in bringing campaign violence under control. The most serious incident had occurred in the town of Masatepe, on 10 December, in which one person died and several resulted injured. According to Center for Democracy observers, stone throwing and fighting was initiated by Sandinista sympathizers; OAS observers, on the other hand, reported they were unable to determine which side started the violence (International Human Rights Law Group, 1990: 39; www.centerfordemocracy.org/elect monitor.nicaragua.html). Be that as it may, during his December visit Carter suggested the SEC spearhead negotiations leading to election guidelines among the parties. The Nicaraguan government agreed to his proposal, and asked him to help in the manufacturing of the proposed agreement (Carter Center, 1990: 18). In 
a fourth visit, on 5-6 January 1990, CC delegation-member Senator Christopher Dodd met with leaders of several political parties and witnessed political rallies (Ibid: 20). In the fifth visit, 26-29 January, led by Carter and former Colombian president Alfonso López Michelse, Carter negotiated with Ortega the release of U.S. funds destined for UNO and other non-Sandinista organizations. Along with UN and OAS observers, delegation members observed a trial of the electoral procedures to be followed on election day. The CC delegation concluded that "excellent technical preparations had been made for the voting." Among the main remaining problems it identified, were ones that had to do with intimidation of opposition party candidates and fiscales (poll-watchers), media access, and FSLN use of state resources during the campaign (Ibid: 20).

Right before the sixth and last pre-election visit, Carter and Pastor went to Washington and met with OAS Secretary General João Clemente Baena Soares and with Elliot Richardson, the UN Secretary-General personal representative. At that meeting, the two IGOs agreed to share the results of their respective quick counts with the CC-something they had been reluctant to do in previous negotiations (Pastor, 2002: 256). This was a major achievement, given that as late as December, both organizations had been disinclined to even carry out a quick count, apparently fearful that this would somehow infringe on Nicaragua's sovereignty.

Previously, Carter had called Baena Soares and UN Secretary-General Javier Pérez de Cuellar, in order to finally sign an agreement (of which there had been almost 20 drafts) among the three organizations, but both had refused to sign the document (lbid: 250). But as Pastor recalls, in a December visit to Managua, "we sat down with the OAS and the UN representatives for two of the most difficult hours of negotiations during that trip... they surprised us by admitting that they were considering doing a quick count, but by themselves. Neither would cooperate with the other or with the Carter/Council (Ibid: 252)." Given that the CC had a much smaller mission that both IGOs, it could not undertake an exercise of this kind; counting with the information would for crucial for it to play a central role on election day.

The last pre-election visit took place 8-11 February, and was led by Belize Prime Minister George Price (Carter Center, 1990: 21). The delegation visited several cities, where they attended rallies and noted that they were taking place in a peaceful manner. Delegation members also noted approvingly the extension of the deadline to name fiscales. However, they also heard about intimidation against UNO's fiscales, and about FSLN members being victims of contra violence. During this visit the CC's delegation was also able to obtain from the Nicaraguan government approval for an increase in the number of U.S. legislators in its delegation, in order to include some members of the Presidential Commission that had been denied governmental approval to attend as observers in the February 1990 elections (lbid: 21).

Thus, the CC's 34-member delegation arrived in Managua on 23 February. At a meeting that day with UNO candidate Violeta Chamorro, government officials Sergio Ramírez and Bayardo Arce, CSE's president Mariano Fiallos, and the heads of the UN and OAS delegations, Prime Minister Price elaborated on the international and bipartisan character of the group. President Carter, for his part, explained how the CC/CFEHG mission would work in tandem with the two IGOs' delegations (Ibid: 22). In a joint press conference held the next day-on the eve of the elections-Carter, OAS Secretary General Baena Soares, and UN Special Representative Elliot Richardson, concluded that "conditions exist in Nicaragua in which the people may freely express their choices on the day of 
the election (Ibid: 22)." With 89 percent of eligible Nicaraguans registered to vote, this time there was more uncertainty about the outcome than in 1984 (Williams, 1990: 23).

On election day, the CC's delegation covered all nine electoral regions, divided into 14 teams. The selection of polling places to be observed was done in coordination with the OAS, and when voting had concluded, CC's observers reported the results to the OAS in order to feed its quick count (Carter Center, 1990: 22-3). Most people, among them analysts, international observers, and even U.S. officials, had been predicting a Sandinista victory (Babbitt, 1990: 17). The FSLN final campaign rally, held on 21 February, gathered more than 600,000 people-outnumbering by far UNO's closing rally. Genaro Arriagada, who had been the speaker of the Executive Secretariat of the Command for the No in Chile's plebiscite and had been invited to Nicaragua by the CC, recalls a delegation meeting on election day in which

I made the case, in light of the Chilean experience, that the Sandinistas, that the idea of losing didn't figure in their minds... but that my hunch was that if in a giver moment on election night, if the opposition's triumph actually happened.. there was going to be a rupture within the regime, and the doves and the hawks were going to split apart... and that in that scenario there was going to be a fight among them, which necessarily needed to be solved in favor of the dove. ${ }^{4}$

Something along those lines did indeed happen. On election night, at 11:30, Ortega requested the presence of Baena Soares, Carter, and Richardson, along with their senior aids, at the FSLN headquarters for a meeting with him, vice-president Ramírez, Foreign Minister D'Escoto, campaign manager Arce, and their American lawyer Paul Reichler. At that time, the OAS, the UN, the CSE, and the government all had preliminary figures showing a clear, irreversible lead of UNO's candidate Violeta Chamorro. At the meeting, the Nicaraguan president expressed his fear that violence could erupt among FSLN's and UNO's activists already celebrating in the streets if UNO prematurely declared victory. As Pastor recalls, president Carter then "urged President Ortega to make a statement before the morning news programs and to take credit for the democratic elections and the achievements of the revolution, while also acknowledging that he was losing and reaffirming his respects for the results (Carter Center, 1990: 25-6)."

Leaving the FSLN's headquarters after 1:00 a.m., the three teams headed to the winning candidate's house. As Ramírez recalls, Carter "took on the function of mediator, which was crucial in order to achieve an understanding with the new government in moments of dangerous uncertainty (Ramírez, 1999: 144)." Part of the problem was of course that the Sandinistas had not contemplated their defeat. As CSE's Fiallos put it, "The fact is that the Sandinista Front was not ready to lose (Interview with Fiallos)." In any case, once in Chamorro's house the three leaders helped negotiate an agreement by both sides to restrain the reaction of their respective followers. Furthermore, Chamorro requested the three leaders the support of their respective organizations to achieve a smooth power transition. As former vice president Ramírez noted later, Carter's role as a mediator during the transitions period was "crucial for reaching an understanding with the new government in moments of dangerous uncertainty (Ramírez, 1999: 144)." Similarly, Antonio Lacayo, Chamorro's campaign manager and later her minister of the presidency and chief advisor, recalls, "president Carter, his person, 
symbolized the issue of international observation, he gave international observation a face... he had a lot of authority over Mores and Christians (Interview with Lacayo)."

At six in the morning, Ortega went on national radio and TV and declared that he would abide by the results; two our later, he conceded the election. Later on the $26^{\text {th }}$, Ortega invited Baena Soares, Carter, and Richardson to with him to Chamorro's house to congratulate her on her victory (Carter Center, 1990: 31). UNO obtained 54.7 of the votes, versus 40.8 of the FSLN. In National Assembly, UNO won 51 sits and the Sandinistas 39 (out of 92 seats). The day after the elections, speaking on behalf of the three major missions at a joint press conference, Carter declared that the electoral process just concluded "had been an impressive demonstration of freedom, democracy, and respect for human rights (A/44/927 (30 March 1990) p. 5)."

\section{The Organization of American States}

The 1990 Nicaraguan elections were a turning point in the OAS' monitoring experience. As Elizabeth Spehar, head of the OAS' Unit for the Promotion of Democracy (UPD) notes, the organization's previous practice in this field was important because "the fact that... a country allowed that an outside organization came to witness the elections that were taking place, and to form an opinion and make it public at the international level" was significant in setting a precedent (Interview with Elizabeth Spehar, Washington, 6 December 2001). Furthermore, as UPD's Santiago Murray has noted, Nicaragua was one of the first countries, in the early 1960's, to request international observers to the OAS, which since then has contributed "in the promotion of the effective exercise [of representative democracy] by means of electoral technical assistance and observation (Murray, 1999: 245)." Nevertheless, Spehar remarks that the pre-Nicaragua 1990 missions were "made within very clear parameters," and they were "limited in time, limited in objectives, limited in capacity, in technical terms (Interview with Spehar)."

Having set a precedent, though, seems to have had an impact on the OAS response to the 1989 Nicaraguan request for electoral observation. As Fiallos recalls, unlike the UN, the OAS had "no problem" in accepting the Nicaraguan government's petition, because the hemispheric organization "was used to observing elections... it didn't seem to the them to be something unusual (Interview with Fiallos)." Thus, a week after Nicaraguan Minister of Foreign Affairs D'Escoto had sent the official request to the OAS, its Secretary General replied that he was "more than willing to provide all my support... I am taking the measures necessary to establish the mechanism to put together the group of international observers (OAS, 1989a: 27)." Less than two weeks after the formal request, Baena Soares was in Nicaragua to observe the release of former members of the National Guard. He also met with president Ortega, members of the CSE, and with representatives of 14 opposition parties (Ibid: 2).

As Baena Soares noted in a preliminary observation report, Nicaragua's request was based on the Esquipulas II framework, in which President Ortega stated his "intention... to develop a process of democratization and national reconciliation within his country (lbid: 1)." For the regional organization, thus, the issue at stake was both regional security (Esquipulas II was after all a regional peace plan)

The prominence achieved by Carter was not well seen by the two IGOs. According to Pastor: "The only feeling shared by officials in the OAS and UN was the professional's disdain for the politician's ability to grab the world's attention, even though that politician, Carter, was a different breed." Pastor (2002): 251. 
and democratic transition in a member-state. Although the latter rationale for observing the electoral process would have lacked validity in other fora, such as the UN, in the OAS it seemed reasonableas the previous discussion of the WHI would suggest.

Thus, the agreement signed between the representative of the Nicaraguan government and the OAS on the privileges and immunities of the organization's observers, states in its preamble that "Article 138 of the Charter of the Organization of American States... provides that: 'The Organization of American States should enjoy in the territory of each Member such legal capacity, privileges, and immunities as are necessary for the exercise of its functions and the accomplishment of its purposes' (OAS, 1989b: 25)." The observing of an electoral process was thus conceived of as being part of the "functions" assigned to the organization.

Unusual or not, the Nicaraguan request to the OAS was at least unprecedented. As Baena Soares noted, the organization experience in Nicaragua in 1989-1990 "was not a passive observation (OAS, 1990: 3)." The OAS endeavor was in fact more than observation-passive or otherwise. The task assigned to the regional organization was one of mediation, making it a central player in the electoral process. Thus, the OAS mission monitored legislative procedures for the reform of the laws on mass media and the electoral law, in compliance with the Costa del Sol agreements. Among other aspects the OAS mission was to cover were: voter registration, election campaign (monitoring of usage of election propaganda, use of radio and TV, access to the media, political rallies, use of resources), observation on election day, tallying process (opening of the ballot boxes, review of the ballots, counting of votes, review of the reports, review of the final results), and the development of a system for following up complaints (OAS, 1989b).

The mission was divided into several phases. In the preliminary one, in July-August 1989, the Secretary General signed two agreements, one with the Nicaraguan government, and one with the CSE, which laid the legal framework for the OAS activities in the Central American country. The first phase properly (i.e., after the preliminary one) covered the period 4 August-23 September, during which an initial group of 18 staff members established themselves in Nicaragua's nine voting districts. The second phase went from 24 September to 23 October, and during it the number of observers was increased to 52 . Their main task was to observe the voter registration process. The preliminary observation and coordination activities continued throughout November, and on 4 December the most intense phase started. It lasted until 20 February 1990, and covered the election campaign period. On election day, there were 433 OAS observers present throughout Nicaragua (OAS, 1990: 3).

As noted, a distinguishing feature of the IEM experience in Nicaragua was the coordination among different monitoring missions. Thus, for instance, Baena Soares' second report notes that his delegation had been holding weekly "coordination meetings" with the UN mission, and that he had met with former president Carter and with Elliot Richardson, in order to coordinate their activities (OAS, 1989b: 2). Beyond this apparently terse relationship, though, there was intense competition for public attention between the three organizations, and, at least between the two IGOs, sometimes there was open animosity. As Pastor observes, "The competition [among the three main observing missions] was most intense between the OAS, which regarded Latin America as its sphere of influence, and the UN, which happened to be led by a Latin American. The comments shared by officials from each organization with us about the other were almost as vitriolic as the ones exchanged between the FSLN and UNO (Pastor, 2002: 251)." 
The sometimes problematic relationship between these last two organizations was partly structural, part of their own making. The structural part was that it was believed that the Sandinistas had invited the UN to check on the OAS, which they did not trust. As former Foreign Minister D'Escoto told me, "We never had very much confidence in the OAS... we felt more comfortable in the worldwide forum, the United Nations (Interview with D'Escoto)." A UN mission member who asked his name not be used told me: "I believe the UN had been invited to counterweight the OAS, and the OAS knew that, so the rivalry was already in place." But the "non-structural" component was also important. As the same informant put it,

the rivalry in Nicaragua [between the UN and the OAS in 1990] was intense, there were people at the UN who were actually persuaded that the OAS was, had infiltrated the UN offices and was, privy to certain phone conversations and, put out a report a few days before we did that resembled in such detail the report that we had drafted that it was amazing, it was remarkable.

But beyond the antagonism between the two IGOs, and the competition between them and the CC, their interaction turned out to be positive. As CC's Pastor noted, "every mission that goes into a country, whether is governmental or intergovernmental, is suddenly competing against each other, while they're trying to do their job, and their competition against each other is how do we do our job better, which is a good thing (Interview with Robert Pastor)." Similarly, Fiallos has noted the "appropriate equilibrium" achieved by the interaction of the CSE and the three main observer delegations (Murray, 1999: 67). In the OAS case, its mission covered all aspects of the electoral process, from voter registration and electoral laws, to voting procedures and the undertaking of a quick count. The last element, as Baena Soares put it in his final report, "was one of the most important items of our activities (OAS, 1990: 3)." With a very large sample (4391 voting places), the OAS mission was able to independently have a very accurate projection of the final results by midnight on election day. Since the regional organization's numbers coincided with those of the CSE, it contributed to ameliorate the state of uncertainty that prevailed among the Nicaraguans that night.

In its final report, the Secretary General concluded that the elections had been "free" and "honest," and praised both the Nicaraguan government and electoral authorities (Ibid: 3, 5). Based on the positive Nicaraguan experience, the Secretary General suggested that "a new perspective of performance [observing the whole electoral process] opens for this Organization," and concluded by stating that "in any future occasion in which this Organization is again asked to provide its collaboration... we will be willing to respond" affirmatively (Ibid: 11,34 ). The reaction by the representatives of the member states was equally enthusiastic. Guatemala's ambassador Miriam Cabrera suggested: "We should find a mechanism so that you, Mr. Secretary General, and your collaborators, can always take part in our countries every time a party of this [electoral] kind takes place in one of them... since we are enthusiastic about the positive results that we ascertain today (Ibid: 15)." Similarly, U.S. representative Luigi Einaudi said that "The delegation organized by the Secretary General is proving to the world that the OAS is very much relevant to the new democratic order that is emerging, not just in our hemisphere, but throughout the world (lbid: 22)."

Edilberto Moreno, the Venezuelan ambassador noted that the OAS was present in Nicaragua "without anybody, government nor opposition, thinking even remotely that we were in the threshold of an undue intervention (Ibid: 25)." Later Uruguayan representative Didier Opertti noted that "the OAS seeks a reasonable space of insertion in the issues of the region. This space brings with it a 
regulated insertion, an insertion that cannot obey either discretionality or free will, but the normative procedures of the system," and that the OAS had acted in Nicaragua "in conformity with the instruments that regulate its life, but also in favor of the international community's opinion (lbid: 2930)." But it fell upon Roger D. Wilson, Canada's Deputy Representative, to propose the creation of what would eventually become the UPD, by noting that his country favored "the development within the OAS of the capacity to observe elections (Ibid: 29)."

\section{The United Nations}

The monitoring of the 1990 Nicaraguan elections was an extraordinary experience for the UN. After receiving the request to observe the elections from the Nicaraguan Foreign Minister in March 1989, Secretary-General Pérez de Cuellar was rather hesitant. He noted that going to a sovereign country was "an exceptional undertaking which breaks new ground in our [the UN's] 44-year history (in Pastor, 2002: 250)." In a letter he sent to the president of the General Assembly the following month, though, he noted that the Nicaraguan request was part of the Central American peace process, and announced that he was going to consider it (in Nolte, 1998: 683). As a UN document would later describe it, the Nicaraguan government's request to observe its 1990 elections "put the United Nations in a very particular situation... there was no precedent for carrying out such observation in an independent country (A/46/609 19 November 1991. Par 28)."

Among the factors that the Secretary-General pondered for his eventual affirmative reply to the Nicaraguan request were the following: "First, it was not a request by a single Member State [but it is inscribed within] the context of the Esquipulas peace process; secondly, the General Assembly, in its resolution 34/24 of 15 November 1988 had requested the Secretary-General 'to afford the fullest possible support to the Central American Governments in their efforts to achieve peace'... Finally, it was not simply a request for a token presence on election day (A/46/609 19 November 1991. Par. 28 )."6

Thus, by 5 July the Secretary-General was ready to establish the United Nations Observer Mission to verify the electoral process in Nicaragua (ONUVEN). Interestingly, almost two months before, on 8 May, he had sent a letter to the OAS Secretary General Baena Soares in which he proposed that the two IGOs observe the Nicaraguan elections jointly. In his reply more than a month later (22 June), Baena Soares noted that his organization had already started the monitoring process, but that he was interested in finding ways in which the two IGOs could collaborate (A/44/642 [20 October 89], p. 5). In any case, when Pérez de Cuellar accepted to observe the Nicaraguan elections, he was careful to note that the undertaking would have "no effect on [the] established practice" of not observing elections in sovereign states (in Stoelting, 1992: 379). Both the General Assembly and the Security Council subsequently expressed their support for the Secretary-General's decision. On 25 August ONUVEN became operational with a 17-member staff.

Telling of the unfamiliar territory the organization was stepping in, at the same time that it was actively involved in the Nicaraguan elections, in January 1990 the UN declined a request from the

6 As the UN Mission's co-leader Nguyen Huu Dong put it: "There is a rule that in order for the UN to observe elections, they have to have an international impact, which is the UN's mandate... Nicaragua entered in this category, since the elections in Nicaragua were part of Esquipulas II, and so they were going to open the way to negotiation for Central America. In that sense, the monitoring mission was completely justified." Interview with Nguyen Huu-Dong, Mexico City, 22 November 2001. 
Romanian government to monitor its first post-communist elections; the stated reason: "the United Nations does not monitor internal elections in a country (Fox, 1995: 1661)." Eventually, ONUVEN would number over 250 members, from 50 countries (United Nations A/46/609 19 November 1991. Par. 34). It was indeed an imposing delegation. As ONUVEN's final report notes,

On 25 February, 207 ONUVEN observers travelled [sic] throughout Nicaragua, using 128 vehicles, two helicopters and four small boats. Assistance of various kinds was provided to the groups of observers by a team of 34 persons stationed at the Managua headquarters and at the regional offices... the observers visited 2,155 JRVs [ballot receiving boards] located in 141 of the 143 municipalities in Nicaragua (A/44/927 [30 March 1990], p. 7).

Perhaps to a greater degree that both the CC and the OAS mission, the UN mission was active in a number of fields. As a UN document puts it, its tasks included "verifying that political parties were equitable represented in the Nicaraguan Supreme Electoral Council and its subsidiary bodies; verifying that political parties enjoyed complete freedom of organization and mobilization, without hindrance or intimidation; verifying that all political parties had equitable access to State television and radio; verifying that the electoral rolls were properly drawn up; and informing the Supreme Electoral Council of any complaints received or any irregularities or interference detected in the electoral process (A/46/609 19 November 1991. Par. 32)."

Shortly before the elections, ONUVEN issued a report in which it noted: "there can be no doubt that, compared with the elections of 1984, the current elections were characterized by greater pluralism, competitiveness and political openness." The pre-electoral report also concluded that "as... the people of Nicaragua go to the polls, they are in a position to decide between alternatives which have been given a reasonable chance to be aired. They will be able to freely determine their future government through the verdict of the ballot-boxes on 25 February 1990 (A/44/921, p. 5)." Publicly stating before the winner was determined that the elections complied with international standards was a calculated decision on the part of ONUVEN-and an important victory for the Sandinista regime. In this victory, though, the accompaniment of international monitoring missions, especially of the UN was particularly important. As the organization would later acknowledge it, its members acted "as conveners, conciliators and, where necessary, as gadflies (A/44/927 p. 3)."

The UN's work was without a doubt wide and professional. Nicaragua-based journalist and Hemisphere Initiatives' observer Judy Butler concurs with the previously quoted nameless UN observer in that the UN did a better than the OAS in observing the elections. Butler says she "was aware of the level of professionalism far higher in the UN [mission] than in the OAS [mission] (Interview with Butler, Managua)." Similarly, CSE's Zelaya noted that "it was the United Nations, more than the OAS that played a crucial role" in the 1990 elections (Interview with Zelaya)."

UN activities were also far more comprehensive than those of the CC. CC-official Jennifer McCoy recognized that unlike the two IGOs, which counted with large staffs who stayed in Nicaragua for a long time, "the Carter Center was there for a month, we just had one field officer which was me, I was the representative there, we didn't have people in all the cities, like the UN and the OAS (Interview with McCoy)." Along the same lines, ONUVEN-member Shelly McConnell, now at the CC, noted that since the UN office was established in August 1989, the mission 
adopted a very complete mandate [in contrast with the CC's mission], I mean, it was wide. We had a technical team, for example, do nothing but examine the news on the media; we had people who examined all the complaints that were registered about things like candidates resigning [...]multilateral organizations phase a problem, of admitting the degree to which they may be treading on sovereignty..... it is true that they are unable to do certain things, and that they hesitate or they want to do it quietly. But in fact, they do quite a lot without taking credit for it because they dare not, so, for example, the UN was doing all those things, none of which the Carter Center did, the UN had many more people on the ground... who stayed for seven months, brought it up to 44 at one juncture [...] then to 250. [...] Carter would show up, and he would see a problem that had surfaced, and he would go solve it. The truth is, there had been six problems, but they had already been solved by the UN through much more systematic everyday work (Interview with McConnell, Atlanta, 4 December 2001). ${ }^{7}$

UN Mission Chief lqba Riza rightly described the UN verification process taking place in Nicaragua as "a step beyond observation," but "a step before administration (in International Human Rights Law Group, 1990: 71)." CSE's Fiallos concurs: "In 1990 there was no observation [on the part of the UN], there was a verification (Interview with Fiallos)."

ONUVEN concluded that the electoral process "could be evaluated as free and fair (A/44/927 [30 March 1990], p. 1)." The final report praises the job performed by the electoral authorities, emphasizing ONUVEN's "entirely positive assessment of the activities of CSE and of all levels of the electoral authority, which ensured that the electoral process was impartial and fair throughout (Ibid: 12)." According to the report, 94.3 of voting places functioned normally; 5.3 percent functioned with minor difficulties that did not affect the results, and 0.5 percent experienced serious problems (lbid: 9 ).

The mission carried out the already mentioned quick count which, according to a later UN document "proved to be crucial in the overnight efforts by the Secretary-General's Personal Representative, Elliot Richardson, the Secretary General of the [OAS] and former United States President Jimmy Carter, involving the President of Nicaragua and the victorious opposition coalition (A/46/609 19 November 1991. Par. 35)." The agreement reached that night between the Sandinistas and UNO on controlling each side's supporters, in which the international organization played a mediating role, "was a key factor in ensuring the successful initiation of the transitional efforts in which the United Nations played an important role Ibid: Par 35)."

Tellingly, ONUVEN's final report recognized the precedent-setting effect of the endeavor just culminated. It rightly noted that the United Nations was "likely in the future to be called upon similar assignments (A/44/927 [30 March 1990], p. 3)." Indeed, four months later, Haiti officially requested the observation of its forthcoming Presidential elections. Unlike the Nicaraguan case, though, there was no international component to the Haitian request. Nonetheless, sign of the new times, the UN established the United Nations Observer Group for the Verification of Elections in Haiti.

Although no U.S. or Soviet citizen was supposed to be a member of ONUVEN (due to the Cold War environment that still permeated when the negotiations started in the UN), McConnell was hired because she was working in Costa Rica at the time and could somehow be considered a "local hire." Additionally, although she performed as an observer, she was technically hired as a "research assistant." Nevertheless, a Soviet counterpart was soon hired to make up for their presence in ONUVEN. 


\section{CONCLUSIONS}

The myriad of international NGOs present in Nicaragua in 1990 attest both to the salience of the WHI as well as to the significance of this case for the history of IEM. Indeed, with the Nicaraguan experience, a solid IEM Transnational Advocacy Network emerged. But this was not merely a nonstate-actors business-and the presence of the two most significant IGOs was no accident. NGOs and IGOs converged in Nicaragua in large part due to the auspicious environment the WHI had created in the region.

The contrast between the initial responses of the OAS and the UN to the Nicaraguan request is illustrative in this respect. Feeling at home with the Nicaraguan petition, the regional organization had no problem responding affirmatively to it; the UN, on the other hand, was much more wavering in its initial reaction. It knew it was venturing into unknown territory. Nevertheless, the world organization felt compelled to play a role in the isthmus.

Furthermore, as suggested in the preceding pages, the Nicaraguan experience also became crucial in the redefinition of state sovereignty. It was the normative structure that held the western hemisphere together which made the groundbreaking international monitoring of the Nicaraguan 1990 elections possible. But by means of the Sandinistas' assent of foreign actors getting actively involved in what used to be constructed as a purely domestic affair, the idea of what being a sovereign state means in international affairs was partially altered by this foundational experience.

I am not suggesting that the Sandinistas agreed to the international monitoring of their elections merely for idealistic reasons. Rather, they accepted it on pragmatic grounds. They knew that they were being compelled to open up the electoral process to international scrutiny and, acting strategically, used the opportunity to attempt to save their revolutionary project. In this sense, the eventual seal of approval by the three main monitoring organizations would act as an insurance against continued aggression by the United States.

But beyond the issue of the extent to which IEM was forced on the Nicaraguans, there is a simple fact: IEM had become a modern "requirement." Like the one of colonial times, the modern requirement speaks to the importance of the normative element even in the intercourse among different social groupings-with one crucial difference: the recent variety was part and parcel of a shared normative structure, the WHI. That is, in the Nicaraguan case, participants shared what Jürgen Habermas calls a "lifeworld."8 By lifeworld Habermas means "a culturally transmitted and linguistically organized stock of interpretive patterns." The existence of a common "lifeworld" is what makes the existence of communicative action, and therefore of both principled and strategic decisions, possible in the first place. Thus, for instance, the states of the Americas possessed not only a shared stock of knowledge and distinct and recognized personalities, but also a sense of belonging to a distinct society, the one demarcated by the WHI. Both foreign observers and Nicaraguans were acting within this common background. This is what is telling about the changes in state sovereignty partially brought about by the Nicaraguan experience-the hemispheric normative structure that required and made IEM possible.

The constructivist argument presented here certainly lacks the parsimony favored by some rationalist approaches (e.g. neorealism and liberal institutionalism). Thus, for instance, it could be argued that 
Nicaragua accepted massive foreign observation in 1990 simply because it was forced to. The rationale for preferring this leaner argument would apparently be consistent with "Ockham's razor," also known as the "law of parsimony": non sunt multiplicanda entia praeter necessitatem (entities are not to be multiplied beyond necessity) (in Audi, 1995: 545). Nevertheless, the argument of the medieval monk was more subtle than "keep it simply," the way in which it is usually interpreted. The crux of Ockham's dictum is that any baggage in excess of that required for the understanding of the issue at hand should be dispensed of. That is, Okcham's razor is not an injunction for the simplest theory, but for the one that is capable of elucidating the problem to be explained without superfluous information.

The, rationalist critique of my argument would then need to be that some of the alleged causal factors in my constructivist argument are unnecessary to explain 1) the monitoring of the Nicaraguan electoral process, 2) the emergence of an IEM network, and 3) its concomitant contribution for the redefinition of state sovereignty. I offer two rejoinders: 1) The more extensive argument I present does not include unnecessary information for answering the composite puzzle in question: how was it that an international norm originated in the Nicaraguan 1990 elections; 2) The focus on process (as opposed to outcome) sheds more light on the complex international-domestic, statenon state actors interactions than a quick and dry neorealist-type kind of explanation would. My explanation shows how the initial conditions and the outcome are causally and discursively connected. In a recursive fashion, then, the 1990 monitoring of the Nicaraguan elections contributed to make explicit the understanding of sovereignty enshrined in the WHI.

\section{REFERENCES}

Audi, Robert, ed. 1995. The Cambridge Dictionary of Philosophy. Cambridge: Cambridge University Press.

Babbitt, Bruce. 1990. Poll Position. New Republic, 19 March 1990, 17-19.

Callcott, Wilfrid Hardy. 1968. The Western Hemisphere: Its Influence on United States Policies to the End of World War II.

Austin: University of Texas Press.

Carter Center. 1990. Observing Nicaragua's Elections, 1989-1990. Atlanta.

Carter Center. 1996. The Journey to Democracy: 1986-1996. Atlanta.

Corrales, Javier, and Richard E. Feinberg. 1999. "Regimes of Cooperation in the Western Hemisphere: Power, Interests, and Intellectual Traditions." International Studies Quarterly 43 (1):1-36.

Fox, Gregory H. 1995. "Multinational Election Monitoring. Advanced International Law on the High Wire." Fordham International Law Journal 18 (5):1657-1667.

Habermas, Jürgen. 1989. The Theory of Communicative Action. Volume Two: Lifeworld and System: A Critique of Functionalist Reason. Translated by T. McCarthy. Boston: Beacon Press.

Hurd, lan. 1999. "Legitimacy and Authority in International Politics." International Organization 53 (2):379-408.

Inter-American Dialogue. 1992. Convergence and Community: The Americas in 1993. Washington.

International Human Rights Law Group, and Washington Office on Latin America. 1985. From Shadow into Sunlight: A Report on the 1984 Uruguayan Electoral Process. Washington, D. C.: International Human Rights Law Group-Washington Office on Latin America.

International Human Rights Law Group. 1990. Preliminary Report on the Upcoming Nicaraguan Elections. Washington, D. C. López Pintor, Rafael. 1998. "Nicaragua's Measured Move to Democracy." In Postconflict Elections, Democratization and International Assistance, edited by K. Kumar. Boulder: Lynne Rienner. pp. 39-55.

McCoy, Jennifer L. 1998. "Monitoring and Mediating Elections During Latin American Democratization." In Electoral Observation and Democratic Transitions in Latin America, edited by K. J. Middlebrook. San Diego: University of California, 53-90. 
Murray, Santiago. 1999. La OEA y la observación electoral. Paper read at Seminario Internacional sobre Legislación y Organización Observación Electoral: Una Visión Comparativa, at Lima, Perú.

Nolte, Detlef. 1998. "La observación internacional de elecciones." In Tratado de derecho electoral comparado de América Latina, edited by D. Nohlen, S. Picad and D. Zovatto. Mexico City: Fondo de Cultura Económica. Pp. 674-688.

OAS. 1989a. Report of the Secretary General on Observation of the Passage of the Electoral and Mass Media Laws of Nicaragua and the Agreement on the Privileges and Immunities of Observers of the Nicaraguan Election Process. Washington.

OAS. 1989b. Second Report on the Observation of the Nicaraguan Electoral Process (July 13 to November 3, 1989). Washington.D.C.

OAS. 1990. Informe del Secretario General de la Organización sobre su observación del proceso electoral en Nicaragua. Washington. D.C.

Pastor, Robert. 2002. Not Condemned to Repetition: The United States and Nicaragua (Second Edition). Boulder: Westview Press.

Ramírez, Sergio. 1999. Adiós muchachos: Una memoria de la revolución sandiista. Bogotá: Aguilar.

Rico, Carlos F. 1990. "The Contadora Experience and the Future of Collective Security." In Alternative to Intervention: A New U.S.-

Latin American Security Relationship, edited by R. J. Bloomfield and G. F. Treverton. Boulder: Lynne Rienner. Pp. 93-114.

Risse-Kappen, Thomas. 2000. "Let's Argue!': Communicative Action in World Politics." International Organization 54 (1):1-39.

Santa Cruz, Arturo. 2000. Un debate teórico empiricamente ilustrado: la construcción de la soberanía japonesa, 1853-1902.

Guadalajara: University of Guadalajara Press.

Stoelting, David. 1992. "The Challenge of UN-Monitored Elections in Independent Nations." Stanford Journal of International Law 28:371-424.

Weber, Cynthia. 1995. Simulating Sovereignty: Intervention, the State, and Symbolic Exchange. Cambridge: Cambridge University Press.

Wendt, Alexander. 1999. Social Theory of International Politics. Cambridge: Cambridge University Press.

Whitaker, Arthur P. 1954. The Western Hemisphere Idea: Its Rise and Decline. Ithaca: Cornell University Press.

Williams, Philip J. 1990. "Elections and Democratization in Nicaragua: The 1990 Elections in Perspective." Journal of Interamerican Studies and World Affairs 32 (4):13-34.

Arturo Santa Cruz is an Associate Professor at the Universidad de Guadalajara, Mexico. His books are The Economic Impact of Regional Integration in the Pacific Rim (Mexico, 2004), What's the Name? Globalization, Regionalization, and APEC (Mexico, 2003), Un debate teórico empiricamente ilustrado: La construcción de la soberanía japonesa, 1853-1902 (Mexico, 2000). Recent articles include «From Transition to Consolidation: Mexico's Long Road to Democracy» in Revista de Ciencia Politica 22 (2002), and "La política exterior japonesa bajo Koizumi» in review México y la Cuenca del Pacífico (2003).

(E-mail: arturosc@hotmail.com) 